\title{
GHAZAN KHAN : PEMBAHARU MUSLIM DARI MONGOL
}

\author{
Oleh: \\ Zalik Nuryana \\ Dosen Pendidikan Agama Islam Universitas Ahmad Dahlan Yogyakarta \\ Anggota Majelis Pendidikan Kader Pimpinan Daerah Muhammadiyah Kabupaten Sleman \\ Email : zalik.nuryana@pai.uad.ac.id
}

\section{PENDAHULUAN}

Sejarah perjalanan umat Islam memiliki kekhasan tersendiri pada setiap daerah yang diduduki. Islam memiliki sejarah panjang dan variasi model penyebaran yang unik dan berliku. Jika dilihat dari perspektif Barat, maka Islam tidak lebih dari sebuah ajaran yang diperjuangkan dengan darah dan pedang. Namun sebaliknya, justru Islam telah melakukan pembebasan bagi masyarakat lokal yang ditindas atas hegemoni dua imperium besar saat itu yakni Persia dan Romawi (Abdul Karim, 2012:286).

Kemunculan Bangsa Mongol di bawah pimpinan Chengis Khan merupakan bagian dari sejarah dunia yang menarik dan popular, terutama bagi sejarah peradaban umat Islam. Hal ini disebabkan karena, sejarah tidak dapat membuktikan secara akurat tentang babak baru sejarah kejadian bangsa tersebut. Sejarawan juga memberikan respon positif karena Bangsa Mongol meninggalkan sumbangsih dalam kemajuan peradaban. Keturunan Chengis, dalam sejarah Islam bahkan dalam sejarah dunia meninggalkan pengaruh sangat signifikan bagi peradaban umat manusia. Setelah Kublai, maka sejarah Mongol Khan Agung juga berakhir. Pengganti Kublai semuanya lemah, maka wilayah kekuasaan Kublai yang begitu luas terbagi menjadi lima dinasti merdeka ; Dinasti China, Chagtai, Golden Horde, Ilkhan, dan Kerajaan Siberia (2006:48).

Dinasti Ilkhan, adalah salah satu cabang dari Dinasti Mongol yang didirikan Hulagu Khan. Ilkhan dalam bahasa Mongol berarti kepala suku, dalam makna khusus di kalangan Mongol disebut, perwakilan dari pusat kekuasaan Khan Agung di Karakuram. Tidak ada yang berbeda pendapat bahwa Hulagu identik dengan penguasa yang lalim dan kejam, melenyapkan pusat peradaban umat manusia, namun tidak adil jika dinilai bahwa ia tidak menyukai ilmu pengetahuan dan pendidikan serta kegiatan ilmiah. Sejarawan paling popular di zaman Ilkhan bahkan pada abad XIII-XIV M yang tidak ada duanya, Rashid al-Din yang memuju Hulagu tentang kepandaian dan cintanya terhadap filsafat, arsitektur, seni, kimia, dan sebagainya (2006:80)

Dinasti Ilkhan menjadi pusat peradaban dan masa keemasan di masa Ghazan Khan. Ghazan adalah pemimpin yang membawa perubahan kemajuan dan membawa dinasti Ilkhan sebagai dinasti yang paling maju dalam sejarah bangsa Mongol Islam. Tidak banyak yang mengenal Ghazan, ia masuk Islam diikuti oleh pasukannya, dan kemudian menjadikan menjadikan Islam sebagai agama resmi negaranya saat itu.

\section{BIOGRAFI}

Ghazan Khan lahir pada tanggal 4 Desember $1271 \mathrm{M}$ di Abaskun dekat Bandar-eShah, sebelah Tenggara Laut Kaspia (2006:80). Ketika ayahnya, Arghun berkuasa (1284- 
1291), ia telah menjadi Ilkhan ketika berusia 13 tahun, sehingga masa kecil Ghazan banyak dihabiskan dengan kakeknya Abaga (1265-1282) dan dididik untuk mempelajari agama Budha, seperti kepercayaan yang dianut oleh ayah dan kakeknya. Ghazan kecil hidup dalam lingkungan religius agama Budha yang taat. Masa kecil dengan kakeknya yang mengabdikan dirinya sebagai biksu, mempercayakan Ghazan pada satu atau dua guru atau ketua biksu untuk mengajarkan dan membimbingnya menerima doktrin-doktrin agama Budha.

Ketajaman akal, intelektual, dan wawasan yang luas membawa Ghazan cepat memahami esensi-esensi dan makna dari pengajarannya ia menjadikan doktrin, peribadatan, dan seluk beluk komunitas mereka sendiri secara mendalam, dan mencapai sebuah kesempurnaan di dalamnya yang menjadikannya seorang yang ahli dalam bidang keagamaan Budha. Ketika ayahnya menjadi Ilkhan, Ghazan berusia 10 tahun ditunjuk sebagai gubernur Khurasan di bawah bimbingan Amir Nawros, yang telah berpengalaman menjabat di berbagai provinsi Persia sejak masa Chengis dan penerusnya (39 tahun)

Ghazan masuk Islam pada tanggal 19 Juni 1295 M atau 4 Sa'ban 694 H (24 tahun), disertai 100.000 bangsa mongol. Versi lain seperi yang dituliskan Prof Karim dalam buku Islam di Asia tengah (Abdul Karim,2006:86-87), Ghazan masuk Islam disertai 400.000 orang, termasuk para komandan,wazir, dan prajuritnya, bahkan ada yang menyebutkan 10.000 orang.

Proses masuknya Ghazan menjadi Islam, di antaranya, berkat jasa Jendral Nawroz yang membantu perjuanganya melawan sepupunya Baydu, jika ia memenangkan melawan Baydu, ia akan menerima agama Islam. Keterangan lain menjelaskan perubahan kepercayaan itu terjadi ketika terjadi suatu perjanjian dan sebuah persetujuan pada masa Baydu, antara bangsa Mongol dan kaum Muslim Persia. Kaum Muslim bersumpah dengan al-Qur'an dan orang Mongol dengan emas. Dalam pertemuan itu terjadilah dialog antara Nawroz dan Ghazan membahas tentang agama Islam. Selain itu mereka juga memberikan hadiah kepada Ilkhan Baydu berupa potongan mutiara yang sangat indah, tetapi sang Ilkhan mereka tidak diberi apapun sebagai balasannya. Ghazan merasa gusar, setelah peristiwa itu Shekh Sadr al-Din yang mengabdikan seluruh hidupnya untuk melayani sang pemimpin. Ghazan bertanya doktrin-doktrin Islam, sedetail dan sebenar mungkin. Sehingga awal November 1295 Ghazan menambah namanya menjadi Mahmud Ghazan Khan (2006:88). Ghazan Khan wafat pada tahun 1304 M setelah penaklukan ke Syam akibat serangan jantung.

\section{A. PEMBARUAN GHAZAN KHAN}

Ghazan naik tahta secara resmi pada 3 November 1295 dan berusia 24 tahun. Saat Ghazan naik tahta kas Negara kosong. Seperti yang diungkapkan Spuler dalam buku Prof Karim, Harta yang diperoleh berlimpah hasil penakhlukan Baghdad dicuri oleh penjaga, dan digunakan semena-mena sebelum Ghazan (sejak Abaga sampai Arghun), bahkan sampai saat Ghazan naik tahta, tidak tinggal apa-apa (2012:107). Selama Ghazan memerintah ada beberapa pembaruan yang dilakukan sehingga membawa Ilkhan menjadi The Golden Age of Islam Post Baghdad 2012:301).

\section{Bidang Politik-Keagamaan.}

Perpindahan agama Ghazan pada Islam menandai perubahan yang sangat fundamental dalam proses Islamisai di dalam dinasti Ilkhan, yang membuat Ilkhan 
selanjutnya menjadi dinasti yang independen. Ghazan menetapkan Islam sebagai agama resmi negara. Ghazan menyebut dirinya Ruler by the grace of God (Sultan berkat rahmat Ilahi). Ghazan menjalankan pemerintahanya dengan tegas dan bijaksana, ia menciptkan kedamaian dan keamanan. Siapa saja yang dianggap membahayakan kedamaian kerajaan akan disingkirkan tanpa penyesalan. Ia membuat hukumnya sendiri, menerapkan sari'ah di seluruh negerinya dan di berbagai aspek kehidupan.

Ghazan dengan konversi-Islam, kembali memperoleh posisi terhormat atas agama lain. Bagaimanapun kondisi politik tidak menjatuhkan pertahan Islam Sunni terhadap Ilkhan seperti pada masa Saljuq, dan konflik Sunni-Syi'ah lebih berkurang daripada masa sebelumnya. Syi'ah memperoleh kebebasan dan kepercayaan diri mereka kembali berkat pengaruh Nasirudin (1274 M) dan 'Allama Hilli (1326 M). peranan 'Ulama masa Ghazan kembali dimasukkan dalam hirarki kerja negara, kebebasan mereka berkurang tetapi mereka tetap "berada di luar". Mereka diminta menegur Ghazan jika perbuatannya bertentangan dengan shari' ah atau 'aql (Karim, 2006:89-90).

\section{Bidang Sosial-Ekonomi.}

Masa Ghazan khan motif-motif dan gaya Mongol telah berubah secara signifikan. Meskipun Ghazan penerus pemimpin Mongol akan tetapi dia tidak mengikuti kebijakan-kebijakan yang keras. Rashid al-Din mencoba memeriksa kembali beberapa sitem fiskal yang paling banyak disalahgunakan oleh orang-orang Mongol, dengan mengulangi pengumpulan di bawah kekuatan dari penetapan pajak yang tidak teliti, jabatan dari para ilchi (utusan pegawai) dalam populasi lokal, dan kehancuran dari hasil panen karena kecerobohan mereka. Selama ini tidak ada perincian tentang pemasukan dan pengeluaran keuangan Negara.

Sebelum Ghazan petani membayar pajak tambahan, kadang-kadang mereka tidak sanggup membayar pajak karena dinaikkan oleh dinas pajak beberapa kali lipat seperti diuraikan Rashid al-Din dalam buku Prof Karim, “ Kadang-kadang para petani melompat dari atap rumah setelah melihat para petugas pajak sedang kemari ke kampung mereka. Kadang-kadang para petani karena tergesa-gesa untuk menghindari para dinas pajak, melompat dari atap rumah mengakibatkan kaki mereka patah dan lumpuh. Ghazan mengenalkan dengan baik ajaran tentang langkah pemaksaan dengan metode-metode hukuman yang berat bagi yang melanggar peraturan, dan menentukan tingkat perpajakan dengan tepat.

Untuk membantu para petani kecil yang tidak mampu membeli benih bagi kebunnya dan makanan untuk ternaknya, maka Ghazan memerintahkan semua gubernur dan pemungut pajak tani harus menyisihkan dari sejumlah uang pajaknyadengan jumalh tertentu untuk pembelian harga untuk semua binatang yang digunakan tenaganya, benih-benih, dan keperluan pertanian lainnya dalam bukti dokumen, sehingga provinsi-provinsi ini terdapat daftar semua binatang yang dipakai, dan memperkuat perkebunan.

Ghazan adalah satu-satunya penguasa Ilkhan yang sepertinya memiliki kebijakan pertanian. Di bawah kepemimpinannya, didukung Rashid al-Din, yang memiliki perhatian dan pengetahuan tentang pertanian sebagai basis tradisional dari kekayaan negeri, dan berhasil menjadi Negara pengekspor pertama dalam sejarah Ilkhan. Ghazan menghidupkan kembali roda pertanian yang sebelumnya macet total 
dan para petani tidak menggarap sawahnya, karena pajak tinggi, bahkan mereka bakar lading dan berlindung ke hutan. Ghazan juga membangun sejumlah irigasi termasuk kanal besar di daerah Hilla, yang tanahnya telah banyak diolah.

Ghazan juga mencoba memperbaiki kondisi keuangan dengan cara menyusun semua kekayaan yang telah diterima dari provinsi dengan memisahkan harta benda tersebut menurut jenisnya. Ghazan juga mengenalkan metode baru dengan menyusun rumah-rumah penyimpanan kekayaan Negara yang dijaga ketat, dan buku khusus penjaga yaitu buku khusus tentang keperluan uang Negara (Karim, 2006:107-113).

\section{Bidang kemajuan Ilmu dan Budaya.}

Hubungan Ilkhan dengan China dan Eropa telah mengantarkan mereka pada luasnya cakrawala intelektualitas dan menurun hingga keturunannya dalam dinasti Mongol di Persia, Ilkhan. Ghazan adalah seorang pelindung Ilmu Pengetahuan dan Sastra, ia gemar dalam kesenian terutama Arsitektur dan Ilmu Pengetahuan Alam seperti Astronomi, Kimia, dan Mineralogi. Ghazan juga membangun perguruan tinggi untuk Madzhab Syafi'I dan Hnafi, mendirikan perpustakaan dan observatorium (Badri Yatim, 2000:117).

Adapun perkembangan arsitektur dan seni di bidang bangunan fisik semasa Ghazan, yaitu musolium (pusara/kuburan) yang megah sebagai tempat peristirahatannya yang sangat berbeda dengan para raja Mongol sebelumnya. Ghazan banyak menghabiskan dana untuk pembangunan musolium dan sebagai tanda pemberkatan, di sekitarnya dibangun biara untuk para sufi, beberapa perguruan tinggi, sebuah rumah sakit, perpustakaan, observatorium, akademi filsafat, perumahan bagi para Sayyid, sebuah air mancur, dan gedung-gedung publik lainnya. Selain itu muncullah pemukian Ghazaniah, yang ukuran dan kecantikannya mampu melampaui kota Tabris.

Koin yang bertuliskan nama Allah di satu sisi dan Muhammad di sisi satunya, merupakan koin yang muncul di masa Ghazan, yang sebelumnya menggunakan nama Khaqan (Raja Agung), sedangkan kalender yang saat ini masih dikenang berkat jasanya adalah kalender Ilkhan dengan mengubah dasar perhitungan kalender lama dari Syamsiyah ke Qamariyah, dan mengkombinasikannya antara bahasa Mongol dengan nama-nama hari dan bulan dari kalender Hijriyah yang diciptakan Umar ibn Khattab. Sementara manuskrip al-Qur'an berskala besar dan mewah diberikan untuk kepentingan berbagai institusi.

Arsitektur Ilkhan tidak membentuk gaya baru, akan tetapi mengadopsinya dari rancangan bani Saljuq sangatlah popular di bawah Ilkhan. Lukisan miniatur Persia juga dimulai di Mongol pada abad ke-13, ketika pelukis-pelukis Persia dikenalkan pada seni China, dan pelukis-pelukis China bekerja di istana-istana Iran. Tabriz juga merupakan kota pusat lukisan-lukisan kerajaan ilkhan.

Perubahan paling mendasar adalah cabang Islam (Sunni) yang dianut oleh Ghazan, oleh saudaranya, Uljytu diganti dengan Syi'ah Isna Asy'ariyah. Uljytu tidak mengubah sistim ketatanegaraan yang diterapkan oleh Ghazan. Uljytu dikenal dalam sejarah sebagai pembangun berbagai arsitektur dan monument, salah satunya adalah ibu kota baru Sulthaniah, Sulthanabad, dan Camcimal (sebuah kota yang indah). Bandah penggemar seni, budaya, dan sastra. Dengan pemerintahan Rashid al-Din. Pada periodenya jalan-jalan 
banyak diperbaiki dan membuat baru. Setiap satu mil ditandai agar diketahui pengguna jalan. Demikian beberapa hasil peradaban yang pernah ditorehkan oleh dinasti-dinasti Islam di kalangan Mongol. Mereka berhasil membangun imperium baru, sesaat setelah menghancurkan kekuasaan Islam di pusat Bagdad. Wilayah kekuasaan dinasti Mongol mencapai sepertiga luas dunia, hal yang sungguh luar biasa.

Kita dapat mengambil Ibrah dari Ghazan Khan, tentang totalitas ber Islam. Khan menjadikan Islam sebagai dasar landasan dalam kehidupan dan bernegara. Perjuangan dan perjalanannya masuk Islam menjadikan Khan seorang yang di segani pada masanya. Keinginan belajar mendalami Islam membawa nuansa tersendiri dari goresan sejarahnya. Islam yang Rahmatan lil 'Alamin dan mencerahkan tercermin dari sosok Khan.

\section{DAFTAR PUSTAKA}

Karim, Abdul, Islam di Asia Tengah Sejarah Dinasti Mongol Islam. Yogyakarta;Bagaskara. 2006.

Sejarah Pemikiran dan Peradaban Islam, Yogyakarta: Bagaskara, cet IV, 2012.

Yatim, Badri, Sejarah Peradaban Islam,Jakarta;Raja Grafindo Persada.2000. 